\title{
Stability of Citrus tristeza virus protective isolate 'Pêra IAC' according to SSCP analysis of old and new lines of three sweet orange varieties
}

\author{
Waldecy Matos da Silva Leonel ${ }^{1}$; Maria Júlia Corazza ${ }^{2}$; Carlos Alexandre Zanutto ${ }^{2}$; Gerd Walter Müller; Sergio \\ Alves Carvalho ${ }^{3}$ and William Mário Carvalho Nunes ${ }^{2}$
}

${ }^{1}$ Centro Universitário de Maringá - Cesumar, Maringá/PR. ${ }^{2}$ Núcleo de Pesquisa em Biotecnologia Aplicada - NBA e Departamento de Agronomia, Universidade Estadual de Maringá - UEM, Av. Colombo, 5790, CEP 87020-900, Maringá/PR. ${ }^{3}$ Centro APTA Citros Sylvio Moreira - Cordeirópolis -SP. Autor para correspondência: Carlos Alexandre Zanutto (cazanutto@uem.br ). Data de chegada: 01/04/2014. Aceito para publicação em: 16/01/2015.

$10.1590 / 0100-5405 / 1991$

\section{ABSTRACT}

Leonel, W.M.S.; Corazza, M.J.; Zanutto, C.A.; Müller, G.W.; Carvalho, S.A.; Nunes, W.M.C. Stability of Citrus tristeza virus protective isolate 'Pêra IAC' according to SSCP analysis of old and new lines of three sweet orange varieties. Summa Phytopathologica, v.41, n.1, p.8-12, 2015.

Clonal cleaning, followed by pre-immunization with protective complexes of Citrus tristeza virus (CTV), allowed the commercial cultivation of Pêra sweet orange, a variety that has great importance for Brazilian citriculture but is sensitive to the virus. The use of mild protective isolates in other citrus varieties, even those more tolerant to $\mathrm{CTV}$, can also be of interest to prevent the spread of severe isolates. The aim of this study was to characterize, by means of SSCP (Single Strand Conformational Polymorphism) analysis of the coat protein gene, CTV isolates present in plants of the sweet orange cultivars Pêra, Hamlin and Valencia propagated from four budwood sources: 1) old lines, 2) nucellar lines, 3) shoot-tip-grafted lines, and 4) shoot-tipgrafted lines pre-immunized with the mild CTV protective isolate 'PIAC'. We also evaluated the correlation of the obtained SSCP patterns to stem pitting intensity, tree vigor and fruit yield. SSCP results showed low genetic diversity among the isolates present in different trees of the same variety and same budwood source and, in some cases, in different budwood sources and varieties. Considering tristeza symptoms, lower intensity was noted for plants of new, shoot-tip-grafted and pre-immunized shoot-tip-grafted lines, compared to old lines of the three varieties. The observed SSCP patterns and symptomatology suggested that more severe CTV complexes infect the plants of old lines of all three varieties. The protective complex stability was observed in the SSCP patterns of CTV isolates of some shoot-tip-grafted and pre-immunized clones. It was concluded that the changes detected in other electrophoretic profiles of this treatment did not cause loss of the protective capacity of CTV isolate 'PIAC' inoculated in the pre-immunization.

Additional keywords: CTV, cross protection, molecular diversity, symptomatology.

\section{RESUMO}

Leonel, W.M.S.; Corazza, M.J.; Zanutto, C.A.; Müller, G.W.; Carvalho, S.A.; Nunes, W.M.C. Estabilidade do isolado protetivo Pêra IAC do Citrus tristeza vírus observado pela análise SSCP em clones velhos e novos de três variedades de laranja doce. Summa Phytopathologica, v.41, n.1, p.8-12, 2015.

A limpeza clonal seguida de pré-imunização com complexos protetivos do Citrus tristeza virus (CTV) possibilitaram o cultivo comercial da laranja Pêra, variedade de relevante importância para a citricultura brasileira, mas sensível ao vírus. O emprego de isolados fracos protetivos em outras variedades de citros, mesmo com maior tolerância ao CTV, pode ser também de interesse para evitar a dispersão de isolados severos. O objetivo desta pesquisa foi caracterizar, por meio da análise SSCP (Single Strand Conformational Polymorphism) do gene da proteína do capsídeo, isolados de CTV presentes em plantas das cultivares de laranjas doce Pêra, Hamlin e Valência, propagadas de quatro fontes de borbulhas: 1) clones velhos, 2) clones nucelares, 3) clones microenxertados e 4) clones microenxertados pré-imunizados com o isolado fraco protetivo 'PIAC' do CTV. Avaliou-se ainda a correlação dos padrões SSCP obtidos com intensidade de caneluras no lenho, vigor e produção de frutos. Resultados do SSCP demonstraram baixa diversidade genética entre isolados presentes em diferentes plantas da mesma variedade e mesma fonte de borbulhas, e em alguns casos, em diferentes fontes de borbulhas e variedades. Para os sintomas de tristeza, observou-se menores intensidades em plantas dos clones novos, microenxertados e, dos microenxertados pré-imunizados sobre clones velhos das três variedades. Os padrões SSCP e a sintomatologia observados sugeriram que complexos mais fortes do CTV estão infectando as plantas dos clones velhos das três variedades. A estabilidade do complexo protetivo foi observada nos padrões SSCP dos isolados de CTV de alguns dos clones microenxertados e pré-imunizados. Concluiu-se que as alterações detectadas em outros perfis eletroforéticos deste tratamento não provocaram a perda da capacidade protetiva do isolado 'PIAC' de CTV, inoculado na pré-imunização. 
After its introduction into São Paulo State in 1937, the Closterovirus Citrus Tristeza Virus (CTV), which causes quick decline syndrome in citrus, has spread and destroyed the majority of commercial citrus orchards in Brazil with trees grafted onto sour orange rootstock (Citrus aurantium Osb.) (2). Cultivating old-line scion varieties, the citrus industry was restored with the use of CTV-tolerant rootstocks (16). Since 1955 , old lines have been replaced by new lines of nucellar origin, since the former were nearly always infected with other viruses and viroids (12).

Besides quick decline, severe CTV strains also cause stem pitting in citrus. Some sweet orange scion varieties (C. sinensis Osb.), including Pêra, are more susceptible to stem pitting. Pêra is widely cultivated in Brazil, and stem pitting caused by CTV results in yield loss and fruit quality reduction, even when grafted onto rootstocks tolerant to the virus. For nearly 40 years, a nucellar line of this variety had been subjected to immunization with the mild CTV protective isolate 'PIAC', allowing protection against severe strains of the virus (15). More recently, in order to reduce the spread of severe isolates of CTV, the protective isolate 'PIAC' was used in other sweet orange varieties that were cleaned up by shoot-tip grafting and released to the citrus industry (5).

Despite the great success of immunization, some breakdown in cross protection caused by aphids naturally transmitting severe isolates has been described in colder regions of the states of São Paulo (19) and Paraná $(3,7)$. Both for reducing the effects of tristeza stem pitting and for possibly controlling quick decline syndrome in sour oranges, which would allow the continued use of this important rootstock, characterization of isolates and cross-protection mechanisms have been investigated with a focus on strategies for selecting mild isolates that can efficiently exclude severe CTV isolates as a practical measure to control the disease $(1,10)$.

In the present study, we used SSCP (Single Strand Conformational Polymorphism) analysis of the CTV coat protein gene (CPG), associated with the evaluation of tristeza symptomatology, to characterize isolates present in three old lines of sweet orange, nucellar lines, shoot-tipgrafted lines without immunization, and shoot-tip-grafted lines immunized with 'PIAC' as the protective isolate.

\section{MATERIAL AND METHODS}

Trees of sweet orange (Citrus sinensis L. Osbeck), varieties Pêra, Valência and Hamlin, were characterized for CTV. The trees were from an orchard planted in April 1995 at "Centro APTA Citros Sylvio Moreira" of "Instituto Agronômico de Campinas (IAC)", Cordeirópolis, São Paulo State, Brazil. The evaluated budwood was from replicates of each variety of: 1) old lines (OL) - clones derived from budwood introduced into the IAC - Citrus Active Germoplasm Bank (IAC-Citrus AGB) without any control of pathogens; 2) new lines (NL) - clones derived from nucellar embryos that also belong to the IAC-Citrus AGB; 3) - CTV-free clones, obtained through shoot-tip grafting (STG), and 4) - shoot-tip grafted clones immunized with the CTV isolate 'PIAC' (STG\&PR). One plant was sampled per block, with three replicates of each treatment, comprising a total of 36 plants.

Evaluation of CTV symptoms was based on: (a) grading of the vegetative development in the canopy; where $1=$ minimum growth and $5=$ maximum growth, with assessments by three evaluators, taking into account the plant vigor and general health; (b) yield evaluation: fruit production by each tree in each of two years; and (c) scoring of stem pitting severity by sampling branches $(15 \mathrm{~cm}$ length) around the canopies. After removing the bark, stem pitting was graded from 0 (absence) to 5 (most severe stem pitting), based on the diagrammatic scales developed by Müller (14).

For SSCP analysis, the mild CTV isolate 'PIAC' (15) and the severe CTV isolate 'Barão B' were used as positive controls. 'Barão B' causes a severe reaction in sour orange and grapefruit and was characterized by Targon et al. (20). A Pêra sweet orange tree free of CTV and maintained in an aphid-proof screenhouse was used as a negative control. The amplification product of the virus CPG gene was subjected to electrophoresis on a non-denaturing polyacrylamide gel at $8 \%$. The electrophoretic profiles of each sample were obtained by counting the number and the position of bands, and comparisons were made among the CTV isolates obtained from the three sweet orange varieties in each treatment.

\section{RESULTS AND DISCUSSION}

Tristeza symptoms, as evaluated for different budwood sources and varieties, were defined according to vegetative growth, yield and stem pitting intensity (Table 1). Overall yield data and grades attributed to the vegetative development and growth of the trees demonstrated the superiority of STG\&PR, STG and NL compared to OL. In relation to yield, Valência was an exception since its OL material was superior to its NL material and to the OL material from Hamlin and Pêra. No exocortis trunk symptoms were observed for Valencia trees from OL budwood source but Hamlin (OL) did develop these symptoms and this could be attributed to the infection of Hamlin material with exocortis viroid (15). Pêra, the sweet orange most susceptible to CTV, showed the lowest yield for OL budwood, probably due to infection with severe CTV haplotypes.

According to Rossetti and Salibe, (16) Valência sweet orange presents higher tolerance to CTV, compared to Hamlin and even to Pêra, which is reflected by the superior yield performance of OL budwood, compared to those of other varieties. Comparing budwood sources (except that of Pêra), a possible effect of 'PIAC' protection against CTV decline occurred for Valencia and Hamlin. These two varieties had the highest yield observed for STG\&PR treatments. The poorest vegetative development was observed for OL budwood source, which is probably related to its virus and viroid status, including its infection with severe CTV isolates. Except for OL budwood, Hamlin had higher yield and vigor, compared to Valencia and Pêra, which is associated with its genetic characteristics. According to Müller (14), Hamlin has a phenotype of large tree with conical canopies, abundant number of leaves and excellent productivity. Evaluating CTV stem pitting in over two-hundred and fifty accessions of the Citrus Germplasm of IAC, Figueiredo et al. (9) did not mention the reaction of Hamlin sweet oranges; however, this variety was not considered by Müller et al. (15) to be more susceptible to CTV than Pêra sweet orange, grapefruits and Mexican lime.

In agreement with the above-mentioned CTV effect on yield and growth, plants with OL budwood from Pêra variety showed more severe stem pitting, compared to budwood from other sources (Table 1). Moreover, trees with budwood from Hamlin and Valência did not show stem pitting in any treatment, demonstrating tolerance to CTV in these varieties.

The most severe stem pitting in OL budwood accessions of Pêra sweet orange is in agreement with the biological characterization of CTV isolates associated with the variety in Mexican lime indicators previously described by Carvalho et al. (4), as well as with the lower 
Table 1. Yield, growth vigor and stem pitting symptom in plants of three sweet orange varieties propagated from different budwood sources: old lines (OL), new lines (NL), CTV-free shoot-tip grafted clones (STG), and shoot-tip grafted clones immunized with the CTV isolate 'PIAC' (STG\&PR).

\begin{tabular}{ccccc}
\hline & \multicolumn{3}{c}{ Budwood sources } \\
\cline { 2 - 5 } Variety & OL & NL & STG & STG\&PR \\
& & Production Kg fruit/plant* & 114.78 \\
Hamlin & 47.06 & 74.74 & 108.56 & 94.55 \\
Valência & 76.1 & 60.04 & 84.84 & 60.31 \\
Pêra & 27.83 & 59.81 & 58.59 & 2.6 \\
Hamlin & 2 & Growth/vigor & 2.9 & 2 \\
Valência & 1 & 3.3 & 1.6 & 1.3 \\
Pêra & 1.1 & 1.7 & 1.8 & 0 \\
Hamlin & & Branch / stem pitting & 0 & 0 \\
Valência & 0 & 0 & 0 & 1.5 \\
Pêra & 2.3 & 0 & 1 & \\
\hline
\end{tabular}

*Average data of 2003 and 2004

yield obtained for these plants, confirming the need to clean and immunize this accession. This was also evident for budwood from the STG treatment, in which plants were free of CTV but were grown in the field without immunization, showing moderate stem pitting and producing less vigorous plant. Although few or no effects were observed on yield, results indicate that the initially healthy Pêra nursery tress became naturally infected in the field by the brown citrus aphid (Toxoptera citricida) with a CTV isolate more severe than the 'PIAC' protective strain.

Diversity and stability of CTV isolates based on SSCP analysis have been evaluated worldwide in citrus growing areas $(6,8,17,19)$. In the present study, SSCP analysis showed, in general, the occurrence of distinct electrophoretic patterns among the three sweet orange varieties (Figures 1). SSCP patterns from the different Pêra budwood sources indicate variations among CTV isolates, whereas similar isolate patterns were observed within all replicates of this variety in OL, NL, STG budwood treatments and in two replicates of STG\&PR budwood treatments (rows 11 and 12). Similar isolate patterns within replicates would be expected for OL, NL and STG\&PR budwood treatments since the plants were propagated from the same CTV source. Plants of the STG treatment might be expected to have a dissimilarity of patterns among isolates as the plants were exposed in the field to a random infection of CTV isolates as inoculated by the vector. Thus, variation of the CTV populations after host change or aphid transmission may explain in part the wide biological variability observed among CTV isolates.

Similar SSCP patterns between budwood sources were also observed for isolates in both Hamlin and Valência (Figure 1), which might be related to the behavior of the brown citrus aphid vector that flies from one tree to adjacent ones (11), thus locally spreading virus isolates. One of the STG trees may have been inoculated by aphids from one source tree, while the adjacent trees may have been infected by aphids from the first, and so on. However, CTV haplotype complexes established in healthy plants may be the result of a blend of different isolates, randomly inoculated by aphids that had previously fed on
OL, NL, STG or STG\&PR-treated trees in the experiment, or in other surrounding citrus plots. Random and simultaneous inoculation of different isolates into different parts of a tree would prevent predominance of only one isolate, leading to a stable complex with a new molecular pattern, which could be different to that in the first tree. This was observed by Souza et al. (18) and Zanutto et al. (22) and suggests competition between the different haplotypes of the isolates that infected the plant. The electrophoretic profile of the isolates obtained from STG\&PR in the field (plants 11 and 12) were identical to those observed in the mild control 'Pêra IAC' budwood trees (Fig. 1 , row 13), maintained under screen.

The electrophoretic profile of STG\&PR (plant 10) differed from that of 'PIAC'-treated trees only by the presence of an upper band (Fig. 1, row 10). These results and the better performance of these treatments regarding tristeza severity, plant vigor and yield (Table 1) suggest that the protective complex was relatively stable during the eight years since the start of the experiment. The isolate from NL budwood source, which corresponded to the original immunized 'Pêra IAC' sweet orange (13) and was used as a virus source for new immunizations (5), presented two additional upper bands, possibly corresponding to a haplotype not transferred in the immunization operation but carried by a viruliferous aphid fed on the original source.

Healthy Pêra plants taken to the field (STG treatment) slightly differed from 'PIAC' control, suggesting that some additional isolates were disseminated by the vector, as previously discussed. Furthermore, the protective isolate is very invasive (15) and thus could suppress any isolate already present in the trees used in the experiment, even if the isolates were introduced later by vectors. The better performance of NL, STG and STG\&PR budwood sources, compared to that of OL, especially in relation to the yield, suggests the maintenance of the basic compounds of the protective isolate over the experiment. This suggests that the addition or the loss of a band in the basic electrophoretic profile of the protective isolate 'PIAC' does not always imply an alteration in its performance.

The electrophoretic profile of the coat protein gene of CTV isolate 

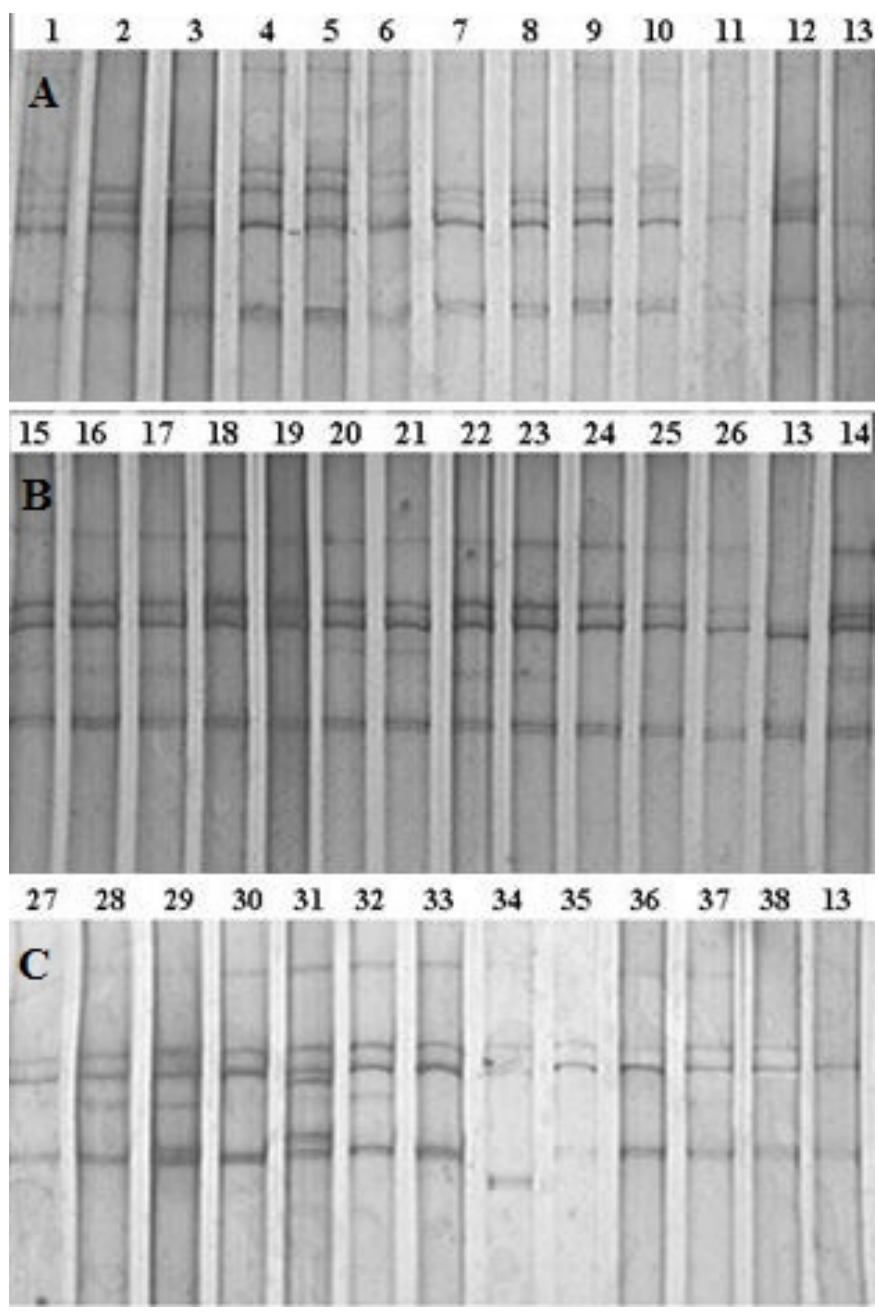

Figure 1. SSCP patterns of CTV isolates on $8 \%$ polyacrylamide gel. (A) - OL $(1,2,3)$, NL $(4,5,6)$, STG $(7,8,9)$ and STG\&PR $(10,11,12)$ of Pêra sweet orange; (B) OL $(15,16,17)$, NL $(18,19,20)$, STG $(21,22,23)$ and STG \& PR $(24,25,26)$ of Hamlin; (C) OL $(27,28,29)$, NL $(30,31,32)$, STG $(33,34$, $35)$, STG \& PR $(36,37,38)$ of Valência. Mild 'PIAC' control (13) and severe 'Barão B' control (14) isolates.

present in the plants from OL source is related to the variations in the molecular composition of its isolate and has already been biologically characterized as severe, compared to 'PIAC' (18). However, the SSCP patterns of CTV from OL plants were also different from those of the positive control 'Barão B', which had severe tristeza (Fig. 1, row 14). A characteristic pattern of bands was observed in the electrophoretic profiles of CTV isolates obtained from the plants of all treatments for Hamlin and Valência. Differences due to the presence, intensity and position of some intermediary bands existed among the profiles of the different treatments and within treatments. CTV isolates of Hamlin sweet orange presented band patterns similar to those of 'Barão B' control (Fig. 1, rows 15, 16, 17 and 14), suggesting that severe isolates may be infecting these plants, without developing stem pitting symptoms, probably due to the higher tolerance of that variety to the virus. No electrophoretic profile of Hamlin isolates was identical to that of the 'PIAC' control (row 13). This may suggest that 'PIAC' protective isolates do not present the same molecular stability in this variety, as observed for Pêra sweet orange in the STG\&PR treatment (especially for plants 11 and 12). CTV isolates that cause severe symptoms were comparable to the protective 'PIAC' isolate infecting Pêra, Hamlin and Valência OL budwood sources. However, only Pêra sweet orange showed poor performance in relation to tristeza due to its greater susceptibility to CTV.

Evaluating the protective capacity of new mild CTV isolates used in Paraná State, Zanutto et al. (22) found that SSCP molecular analysis was an excellent complementary tool for monitoring the performance of the experiments and the stability of the viral complex present in the plants. In Paraná State, tristeza symptoms and SSCP analysis of Pêra Vacinada 58B and 59B, grown from clonal propagations of 'IAC Pêra' immunized material from São Paulo, suggested that the 'PIAC' protective complex in Pêra orange has been kept stable for over six years under field conditions (21). In the present study, some budwood sources for plants of the three tested varieties (STG\&PR budwood source) showed a more stable SSCP pattern, suggesting that the stability of 'PIAC' protective isolate was maintained throughout the eight years of the experiment. The SSCP pattern of 'PIAC' was consistent in both Hamlin and Valência sweet orange.

In spite of the good performance of 'PIAC' mild CTV isolate in protecting against tristeza in the current and in a previous study, superinfection exclusion may occur between isolates of some strains but not between isolates of different strains (10). This paper reveals that searching for new CTV protective isolates should be a constant challenge when growing susceptible varieties of citrus such as Pêra orange in Brazilian regions of mild climate.

\section{REFERENCES}

1. Albiach-Marti, M.R. Molecular Virology and Pathogenicity of Citrus tristeza virus. In: Garcia, M.L; Romanowski, V. (Ed.) Viral genomes: molecular structure, diversity, gene expression mechanisms and host-virus interactions. Rijeka: In Tech, 2012. Cap 14, p.275-302.

2. Bitancourt, A.A. A doença dos citros no Vale do Paraíba. O Biológico, São Paulo, v.6, p268-269, 1940.

3. Carraro, B.P.; Nunes, W.M.C.; Corazza-Nunes, M.J.; Machado, M.; Stach-Machado, D.R. Avaliação de complexos do Citrus tristeza virus da região Norte do Estado do Paraná por meio de testes imunológicos e SSCP do gene da capa proteica. Acta Scientiarum: Agronomy, Maringá, v.25, n.2, p.269-273, 2003.

4. Carvalho, S.A.; Machado, M.A.; Baptista, C.R.; Müller, G.W.; Silvério, J.L. Caracterização biológica de isolados do vírus da tristeza dos citros. Fitopatologia Brasileira, Brasilia, DF, v.22, p.79-84, 1997.

5. Carvalho, S.A.; Machado, M.A.; Müller, G.W.; Coletta Filho, H.D. Produção de borbulha básica para formação de mudas de citros sadias em São Paulo. Laranja, Cordeirópolis, v.22, p.185-201, 2001.

6. Cerni, S.; Nolasco, G.; Krajacic, M.; koric, D. Genetic Variability of Croatian Citrus tristeza virus Isolates. In: Conference of the International Organization of Citrus Virologists, 17., Adana. Proceedings. Riverside: IOCV, 2010. p.190-193.

7. Corazza, M.J.; Zanutto, C.A.; Zanineli-Ré, M.L.; Müller, G.W.; Nunes, W.M.C. Comparison of Citrus tristeza virus (CTV) isolates by RFLP analysis of the coat protein nucleotide sequences and by the severity of the symptoms. Tropical Plant Pathology, Brasilia, DF, v.37, n.3, p.179-184, 2012.

8. Costa, A.T.; Nunes, W.M.C.; Zanutto, C.A.; Müller, G.W. Stability of Citrus tristeza virus protective isolates in field conditions. Pesquisa Agropecuária Brasileira, Brasilia, DF, v.4, n.7. p.693-700, 2010.

9. Figueiredo, J.O.; Pompeu Júnior, J.; Pio, R.M.; Müller, G.W.; Teófilo Sobrinho, J.T. Estudos recentes sobre a ocorrência de caneluras da tristeza em variedades de citros. Laranja, Cordeirópolis, v.14, n.1, p.329-339, 1993.

10. Folimonova, S.Y.; Robertson, C.J.; Shilts, T.; Folimonov, A.S.; Hilf, M.E.; Garnsey, S.M.; Dawson, W.O. Infection with strains of Citrus tristeza virus does not exclude superinfection by other strains of the virus. Journal of Virology, Washington, DC, v.84, n.3, p.1314-1325, 2010.

11. Gottwald, T.R.; Garnsey, S.M.; Cambra, M.; Moreno, P.; Irey, M.; Borbon, 
J.; Sediles, J. A.; Rojas Solis, A. Rate of disease increase and patterns of spread of CTV when vectored by Toxoptera citricida vs. Aphis gossypii. In: Lee, R.; Rocha-Pena, M.; Niblett, C. L.; Ochoa, F.; Garnsey, S. M.; Yokomi, R. K.; Lastra, R. International Workshop (final report): Citrus tristeza virus and the brown citrus aphid in the Caribbean Basin: management strategies, 1985, 3., Lake Alfred. Proceedings. Lake Alfred: University of Florida, 1995. p.44-49.

12. Greve, A.; Prates, H.S.; Müller, G.W. Produção de Borbulhas Certificadas de Citros no Estado de São Paulo In: Rodriguez O, Viegas F (Ed.) Citricultura Brasileira 2.ed. Campinas: Fundação Cargill, 1991. v.1, p.302-317.

13. Müller, G.W.; Costa, A.S. Doenças causadas por vírus, viróides e similares em citros. In: Rodriguez O, Viegas F (Ed.) Citricultura Brasileira 2.ed. Campinas: Fundação Cargil, 1991. v.2, p.252-261.

14. Müller, G.W. Pulgão e tristeza dos citros no Brasil. Laranja, Cordeirópolis, v.17, p.292-293, 1996.

15. Müller, G.W.; Targon, M.L.P.N.; Carvalho, S.A.; Souza, A.A.; Rodrigues, J.C.V. Doenças de citros causadas por vírus e viróides. In: Mattos Júnior D, Negri JD, Pio RM, Pompeu Júnior J (Ed.) Citros. Campinas: Instituto Agronômico e Fundag, 2005. Cap.19, p.569-604

16. Rosseti V.; Salibe A.A. Levantamento das doenças de vírus dos citros no Estado de São Paulo. O Biológico, São Paulo, v.27, p.29-32, 1961.

17. Rubio, L.; Guerri, J.; Moreno, P. Characterization of Citrus tristeza virus isolates by single strand conformation polymorphism analysis of DNA complementary to their RNA population. In: Conference of the
International Organization of Citrus Virologists, 14., 1998, Campinas. Proceedings. Riverside: IOCV, 2000. p.12-17.

18. Souza, A.A.; Müller, G.W.; Targón, M.L.P.N.; Colleta Filho, H.D.; Machado, M.A. Avaliação de haplótipos do gene do capsídeo do Citrus tristeza vírus em plantas pré-imunizadas de laranja Pêra. Summa Phytopathologica, Botucatu, v.28, p.154-159, 2002.

19. Souza, A.A.; Carvalho, S.A.; Targon, M.L.P.N.; Müller, G.W.; Machado, M.A. Characterization of Citrus tristeza virus isolates by SSCP of the coat protein gene in initially healthy sweet orange varieties after three years of field exposure. In: Conference of the International Organization of Citrus Virologists, 14., 1998, Campinas. Proceedings. Riverside: IOCV, 2000. p.131-135.

20. Targón, M.L.P.N.; Nikolaeva, O.; Manjunath, K.L.; Lee, R.F.; Muller, G.W.; Machado, M.A. Coat protein gene of a Brazilian isolate of the Citrus Tristeza Virus: cloning, expression in E. coli and production of polyclonal antiserum. Fitopatologia Brasileira, Brasilia, DF, v.22, n.1, p.99-102, 1997.

21. Temporal, W.M.; Corazza, M.J.; Zanutto, C.A.; Nunes, W.M.C.; Müller, G.W. SSCP analysis of Citrus tristeza virus protectives isolates in Pêra sweet orange clones under northern Paraná state, Brazil conditions. Citrus Research \& Technology, Cordeirópolis, v.32, n.1, p.9-16, 2011.

22. Zanutto, C.A.; Corazza, M.J.; Nunes, W.M.C.; Müller, G.W. Evaluation of the capacity of new mild Citrus tristeza virus (CTV) isolates selected for a preimmunization program. Scientia Agricola, Piracicaba, v.70, n.2, p. 116-124, 2013. 